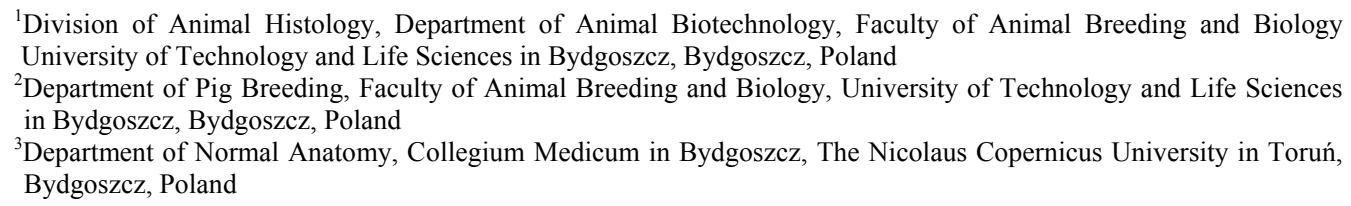
KONRAD WALASIK ${ }^{1}$ and KATARZYNA LIDIA LEWANDOWSKA ${ }^{1}$

\title{
Comparison of microstructural traits of Musculus longissimus lumborum in wild boars, domestic pigs and wild boar/domestic pig hybrids
}

\begin{abstract}
The aim of the present study was to compare the histological structure of muscles in wild boars, pigs and wild boar/domestic pig hybrids by determining the percentage of different muscle fibre types and diameters and the intramuscular fatty tissue content of the Musculus longissimus lumborum (LL). The study involved 24 males representing three groups: wild boars (6 animals), pigs (12 animals: 6 of Polish Landrace and 6 of Duroc breeds) and wild boar/domestic pig hybrids (6 animals). Wild boar/domestic pig hybrids were obtained by crossing DU pigs with wild boars. Samples of the LL were frozen in liquid nitrogen. Frozen muscle samples were cut into 10$\mu \mathrm{m}$ sections. These were later placed on a glass slide and stained using different histochemical reactions: NADH-TR and myofibrillar ATP-ase activity to distinguish muscle fibre types and Oil Red staining to determine the intramusuclar fatty tissue content. The highest proportion of slow twitch oxidative fibres and fast twitch oxidative fibres, being indicative of high meat value, was characteristic of wild boar muscles. The lowest diameters of all three muscle fibre types, associated with the largest number of fibres in the analysed area, suggest that the meat had the most delicate structure. Compared to wild boars, wild boar/domestic pig hybrids showed a decrease in the percentage of oxidative fibres and an increase in the percentage of glycolytic fibres. The diameters of all muscle fibre types in this group of animals were similar to those obtained in pigs.
\end{abstract}

Keywords: pigs, wild boars, wild boar/domestic pig hybrids, muscle microstructure, fatty tissue content, M. longissimus lumborum

\section{Zusammenfassung}

Titel der Arbeit: Vergleich von Muskelstrukturmerkmalen des Muskulus longissimus lumborum bei Wildschwein-, Hausschwein- und Kreuzungsebern

Ziel dieser Arbeit war der Vergleich histologischer Muskelstrukturmerkmale von Wild-, Hausschweinen und deren Kreuzungen, des Anteils der unterschiedlichen Muskelfasertypen, deren Durchmesser und des intramuskulären Fettgehaltes des Muskels M. longissimus lumborum (LL). Einbezogen waren 24 männliche Schweine der genetischen Gruppen Wildschwein $(n=6)$, Polnische Landrasse $(n=6)$, Duroc $(n=6)$ und Kreuzungen Duroc $\times$ Wildschwein $(\mathrm{n}=6)$. Die LL Proben wurden in flüssigem Stickstoff gefroren und $10 \mu \mathrm{m}$ dicke Gefrierschnitte hergestellt. Diese wurden zur Ermittlung der Muskelfasertypen und des intramuskulären Fettgehaltes auf Objektträger aufgetragen und mit NADH-TR und ATP-ase behandelt. Wildschweinmuskeln wiesen die höchsten Anteile an roten und intermediären Muskelfasern auf. Die niedrigsten Durchmesser aller drei Fasertypen war mit der größten Faseranzahl des untersuchten Muskels verbunden was darauf hindeutet, dass dieses Fleisch die zarteste Struktur hatte. Der Vergleich der Wildschweine mit den Kreuzungstieren zeigte bei letzteren eine Abnahme der oxidativen und eine Zunahme der glykolytischen Muskelfasertypen. Außer beim Wildschwein waren die Durchmesser der drei Fasertypen beim Vergleich zwischen diesen drei Populationen ähnlich.

Schlüsselwörter: Schwein, Wildschwein, Wildschwein-Hausschweinkreuzung, Muskelfaserstruktur, intramuskulärer Fettgehalt, M. longissimus lumborum 


\section{Introduction}

The meat of wild boars is considered a delicacy thanks to its good taste and low fat content (ZMIJEWSKI and KORZENIOWSKI, 2001). However, the procurement of venison is limited because of the size of the wild boar population and due to species conservation which restricts the hunting season. Pork is the most popular meat in Europe. The high consumption of pork has encouraged researchers to improve its dietetic value and raw material quality. The overall yield of lean meat can be improved by crossing pigs with the wild boar (Sus scrofa ferus). The combination of these phylogenetically different genotypes makes it possible to produce new-quality food that meets the growing nutritional demands of consumers. To meet the demands of consumers, who are increasingly motivated by the health value of food and the conditions under which raw material was obtained, the breeding of wild boar/domestic pig hybrids was started to combine the nutritive value of wild boar meat with the technological value of slaughter material obtained from cultural breeds, i.e. Sus domesticus (WALKIEWICZ et al., 2004).

The aim of the present study was to compare the histological structure of muscles in wild boars, pigs and wild boar/domestic pig hybrids by determining the percentage of different muscle fibre types and diameters and the intramuscular fatty tissue content of the LL.

\section{Material and methods}

\section{Animals}

The study involved 24 males representing the groups: wild boars, pigs and wild boar/domestic pig hybrids. Wild boars were obtained during hunting in 2005 and 2006. Pigs were of the Polish Landrace and Duroc breeds. Wild boar/domestic pig hybrids were obtained by crossing Duroc pigs with wild boars $(q$ Duroc $\times \widehat{\delta}$ wild boar, $50 \%: 50 \%$ ). All pigs and wild boar/domestic pig hybrids were kept under the same environment conditions (10 animals in pen) and fed ad libitum by all-mash in accordance with feeding standards for pigs (Feeding standards for pigs, 1993). The details related to groups of animals are placed in table 1.

Table 1

Animal groups, weight and age at slaughtering (Tiergruppen, Schlachtgewicht und -alter)

\begin{tabular}{lcccc}
\hline Trait & Wild boars & Polish Landrace & Duroc & $\begin{array}{c}\text { Wild boar/domestic } \\
\text { pig hybrids }\end{array}$ \\
\hline $\mathrm{n}$ & 6 & 6 & 6 & 6 \\
weight at slaughtering (kg) & $51.0 \pm 1,5 \mathrm{~kg}$ & $105.0 \pm 5 \mathrm{~kg}$ & $105.0 \pm 5 \mathrm{~kg}$ & $69.5 \pm 8 \mathrm{~kg}$ \\
age at slaughtering (days) & $*$ & 190 & 190 & 240 \\
\hline
\end{tabular}

* wild boars in second year age

Determination of the microstructure of $L L$

Samples of the LL were taken from pigs and wild boar/domestic pig hybrids for histological analysis $45 \mathrm{~min}$ post mortem. Directly after taking, the samples were frozen in liquid nitrogen at -196 . For wild boars, the whole muscle was chilled and transported to the Laboratory of the Animal Histology Division, where samples were taken and frozen in liquid nitrogen. Frozen muscle samples were cut into $10-\mu \mathrm{m}$ sections using a cryostat. These were later placed on a glass slide and stained using different histochemical reactions: NADH-TR and myofibrillar ATP-ase activity to distinguish muscle fibre types (STO - slow twitch oxidative, FTO - fast twitch 
oxidative and FTG - fast twitch glycolytic) according to ZIEGAN (1979) and Oil Red staining to determine the intramuscular fatty tissue content according to DUBOWITZ et al. (1973). Muscle fibre diameters, percentage of STO, FTO and FTG fibres, number of fibres per $2 \mathrm{~mm}^{2}$ area, and intramuscular fatty tissue content per $4 \mathrm{~mm}^{2}$ area were determined using the Q500MC image analysis system (Leica).

\section{Statistical analysis}

Each trait was analysed statistically by calculating the arithmetic mean $(\bar{x})$ and standard deviation (s). Significant differences between the groups were tested using variance analysis and Duncan's test. All the calculations were made using STATISTICA 5.1 PL software.

\section{Results}

Table 2 and figures 1-6 shows the results of histological analyses for the LL of wild boars, pigs and wild boar/domestic pig hybrids. The highest percentage of STO (red) fibres was characteristic of the meat of wild boars. The proportion of STO fibres in wild boars was the highest $(25.74 \%)$ and differed in comparison with other groups of animals. A similar relationship was found for FTO (intermediate) fibres, which were also the most abundant in the muscle of wild boars $(41.08 \%)$. These animals had the smallest number of FTG (white) fibres $-33.18 \%$. The lowest proportion of oxidative fibres STO and FTO (15.06 and 22.73\%) and the highest proportion of FTG fibres $(62.21 \%)$ were characteristic of the muscles of Duroc pigs. In wild boar/domestic pig hybrids, there was a decrease in the percentage of oxidative fibres and an increase in glycolytic fibres compared to wild boars. Analysis of the number of muscle fibres in the area studied showed that wild boars had the largest number of fibres (529.83), and Polish Landrace (302.17) and Duroc pigs (305.17) had the smallest number of fibres. Wild boar/domestic pig hybrids had an intermediate value of this trait (424.00 fibres per $2 \mathrm{~mm}^{2}$ area). The smallest diameters of all fibre types were found in wild boars (STO - 34.91, FTO - 30.29, FTG - 34.26 $\mu \mathrm{m}$ ). The muscles of Sus scrofa ferus also had the highest intramuscular fatty tissue content $(3.11 \%)$, but did not differ significantly in relation to the other groups of animals.

Table 2

Traits of LL microstructure in wild boars, pigs and wild boar/domestic pig hybrids (Mikrostukturmerkmale des LL bei Wild-, Hausschweinen und deren Kreuzungen)

\begin{tabular}{|c|c|c|c|c|c|c|c|}
\hline \multirow{2}{*}{\multicolumn{2}{|c|}{ Trait }} & \multirow{2}{*}{\multicolumn{2}{|c|}{ Wild boars }} & \multicolumn{3}{|c|}{ Pigs } & \multirow{2}{*}{$\begin{array}{l}\text { Wild boar/domestic } \\
\text { pig hybrids }\end{array}$} \\
\hline & & & & Polish 1 & landrace & Duroc & \\
\hline $\begin{array}{l}\text { Proportion of fibres, } \% \\
\text { in } 2 \mathrm{~mm}^{2}\end{array}$ & $\begin{array}{l}\text { STO } \\
\text { FTO } \\
\text { FTG }\end{array}$ & $\begin{array}{l}25.74^{\mathrm{aA}} \\
41.08^{\mathrm{aA}} \\
33.18^{\mathrm{cB}}\end{array}$ & $\begin{array}{l}7.77 \\
5.78 \\
8.97\end{array}$ & $\begin{array}{l}21.94^{\mathrm{a}} \\
29.33^{\mathrm{bB}} \\
48.73^{\mathrm{bA}}\end{array}$ & $\begin{array}{l} \pm \quad 3.00 \\
\pm \quad 5.27 \\
\pm \quad 7.88\end{array}$ & $\begin{array}{l}15.06^{\mathrm{bB}} \pm 3.97 \\
22.73^{\mathrm{cB}} \pm 3.83 \\
62.21^{\mathrm{aA}} \pm 3.66\end{array}$ & $\begin{array}{r}15.70^{\mathrm{bB}} \pm 3.63 \\
30.38^{\mathrm{bB}} \pm 5.38 \\
53.92^{\mathrm{abA}} \pm 6.30\end{array}$ \\
\hline Fibre diameter, $\mu \mathrm{m}$ & $\begin{array}{l}\text { STO } \\
\text { FTO } \\
\text { FTG }\end{array}$ & $\begin{array}{l}34.91^{\mathrm{bB}} \\
30.29^{\mathrm{B}} \\
34.26^{\mathrm{B}}\end{array}$ & $\begin{array}{l}6.00 \\
2.99 \\
4.61\end{array}$ & $\begin{array}{l}44.54^{\mathrm{a}} \\
42.99^{\mathrm{A}} \\
54.56^{\mathrm{A}}\end{array}$ & $\begin{array}{l} \pm \quad 6.01 \\
\pm \quad 7.30 \\
\pm \quad 6.52\end{array}$ & $\begin{array}{l}47.83^{\mathrm{aA}} \pm 7.05 \\
42.16^{\mathrm{A}} \pm 3.97 \\
52.21^{\mathrm{A}} \pm 4.73\end{array}$ & $\begin{array}{l}48.90^{\mathrm{aA}} \pm 4.02 \\
38.93^{\mathrm{A}} \pm 3.09 \\
49.55^{\mathrm{A}} \pm 4.80\end{array}$ \\
\hline \multirow{2}{*}{\multicolumn{2}{|c|}{$\begin{array}{l}\text { Total fibre diameter, } \mu \mathrm{m} \\
\text { No. of fibres per } 2 \mathrm{~mm}^{2} \text { area } \\
\text { Fatty tissue content, } \% \\
\text { (histochemically) }\end{array}$}} & $\begin{array}{r}33.16^{\mathrm{B}} \\
529.83^{\mathrm{A}}\end{array}$ & $\begin{array}{l} \pm \quad 4.89 \\
\pm 191.29\end{array}$ & $\begin{array}{r}47.36^{\mathrm{A}} \\
302.17^{\mathrm{B}}\end{array}$ & $\begin{array}{l} \pm 8.16 \\
\pm 95.51\end{array}$ & $\begin{array}{r}47.40^{\mathrm{A}} \pm 6.62 \\
305.17^{\mathrm{B}} \pm 68.66\end{array}$ & $\begin{aligned} 45.79^{\mathrm{A}} & \pm 6.27 \\
424.00 & \pm 66.45\end{aligned}$ \\
\hline & & 3.11 & 1.76 & 2.37 & \pm 2.09 & \pm 1.60 & \pm 1.09 \\
\hline
\end{tabular}

$\mathrm{a}, \mathrm{b}=$ differences significant at $\mathrm{p} \leq 0.05 ; \mathrm{A}, \mathrm{B}=$ differences significant at $\mathrm{p} \leq 0$ 


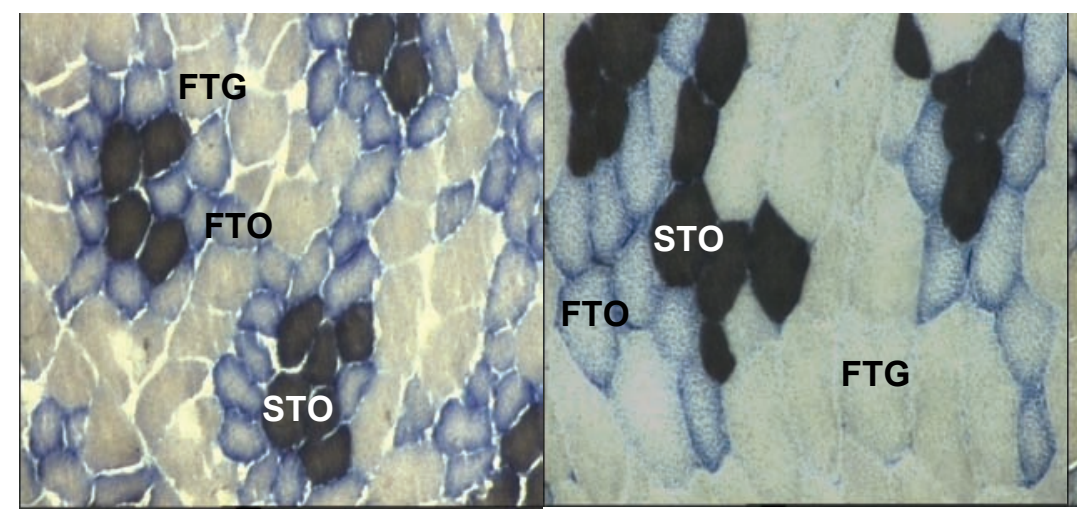

Fig. 1: Cross-section of wild boar LL. Muscle fibres types. Mag. $12.5 \times 10$
Fig. 2: Cross-section of Polish Landrace pig LL. Muscle fibres types.

Mag. $12.5 \times 10$
Fig. 3: Cross-section of wild boar/ domestic pig hybrid LL. Muscle fibres types. Mag. $12.5 \times 10$

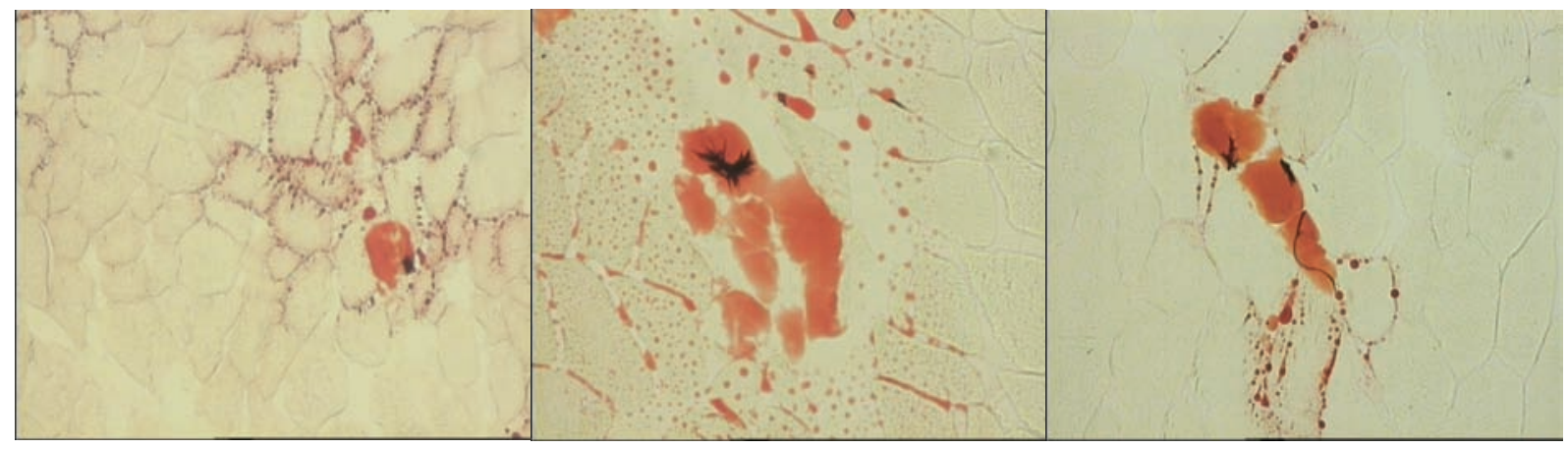

Fig. 4: Cross-section of wild boar LL. Intramuscular fatty tissue. Mag. $12.5 \times 10$

$\mathrm{LL}=$ Musculus longissimus lumborum
Fig. 5: Cross-section of Polish Landrace pig LL. Intramuscular fatty tissue.

Mag. $12.5 \times 10$
Fig. 6: Cross-section of wild boar/ domestic pig hybrid LL. Intramuscular fatty tissue. Mag. $12.5 \times 10$

\section{Discussion}

Three types of muscle fibres: STO, FTO and FTG were defined in muscles of wild boars, pigs and wild boar/domestic pig hybrids using combined reaction for determination of activity of two enzymes: NADH-TR and miofibrillar ATP-ase (ZIEGAN, 1979). It was stated that wild boars had the highest percentage share of oxidative fibres (STO and FTO) and the lowest content of glycolytic fibres (FTG) compared to Polish Landrace, Duroc and wild boar/domestic pig hybrids. In wild pigs, the percentage of FTG fibres in muscle is significantly lower than in domestic pigs (BADER, 1983; SZENTKUTI and SCHLEGEL, 1985). It was observed that during domestication process, contractile properties of fibres changed into faster twitch character. Similar results in different muscles were also shown in studies of ESSENGUSTAVSSON and LINDHOLM (1984), WEILER et al. (1995), FIEDLER et al. (1998) and RUUSUNEN and PUOLANNE (2004). The latest investigations showed that total number of fibres in pig muscles is fixed genetically in prenatal and earlier neonatal period. Postnatal muscle mass depends on increase of muscle fibres length and thickness (ASHTON et al., 2005; KLOSOWSKA et al., 2005; LEFAUCHEUR and ECOLAN, 2005; REHFELDT, 2005; REHFELDT and KUHN, 2006). The profile of muscle fibres is determined not only by genes and their polymorphism, but by many environmental factors. LEFAUCHEUR and GERRARD (1998) showed, that percentage 
participation of fibres and their diameter depends on species, kind of muscle, breed, sex and animals nutrition. Influence of physical activity is also significant. SZENTKUTI and SCHLEGEL (1985) showed, that higher proportion of type I (STO) in LL of wild boars, is genetically determined. Own research showed, that living conditions together with higher physical activity of wild boars in comparison with pigs and wild boar/domestic pig hybrids, would also have influence on profile of muscle fibres. KLOSOWSKI et al. (1988) obtained similar results conducted in investigations on the European Bison, lowland black-and-white cattle and the hybrids of the European Bison $\times$ domestic cattle. Mentioned authors showed higher percentage participation of oxidative type of muscle fibres (STO and FTO) in European Bison compared to hybrids and cattle. As the authors explain there is relationship between physiological function and microstructure of muscle. The muscles of animals living in wild and shifting intensively towards seeking food, carry into effect a long-lasting work, thus exciting mainly in them oxidative metabolism. WATERS et al. (2004) noticed, that endurance training induces angiogenesis in subpopulation of FTG fibres, driving to transformation of white fibres into intermediate fibres (FTO).

In present studies wild boars had also the smallest diameters in all types of fibres and the highest number of fibres per unit of muscle cross section surface. Similar results were given in LACHOWICZ et al. (2004) work, where structure of different muscles of pigs and young wild boars was compared. The wild boars meat had smaller fibre surface, lower intramuscular fat content and thicker peri- and endomysium compared to meat of piglets. The fine fibrous quality, which characterizes wild boar meat in present studies, is a trait of consumer desire and good quality indicator. This is confirmed by results of KLOSOWSKA et al. (2002) and BOGUCKA and KAPELANSKI (2004) studies, which showed, that better meat quality traits were associated with finer microstructure of LL.

There were no significant differences between investigated groups of animals in percentage share of intramuscular fatty tissue determined by histochemical method. KORZENIOWSKI et al. (1991) using chemical method, estimated joint of pork fat content in wild boars of different age, on the level of 1.97-4.82\%. Moreover, ZMIJEWSKI \& KORZENIOWSKI (2001) got the percentage share of intramuscular fat in M. longissimus dorsi at the level of $1.95 \%$, and in ham muscles $-2.76 \%$. In the present study, fat content appeared to be higher. The possible reason is that wild boar biological material was obtained in autumn-winter hunting season, when body weight and fatness of Sus scrofa ferus are higher than in remaining seasons. It is also visible, that STO fibres diameter in wild boars is the biggest and it even excels the diameter of FTG fibres. As it is shown in many studies conducted by diverse authors (KLOSOWSKA et al., 1998, 2002; BOGUCKA and KAPELANSKI, 2004, 2005) on meat of pigs, diameters of FTG fibres are always bigger compared to STO fibres diameters. In conclusion, the present study showed that the highest proportion of STO and FTO oxidative fibres, being indicative of high meat value, was characteristic of wild boar muscles. The lowest diameters of all three muscle fibre types, associated with the largest number of fibres in the analysed area, suggest that the meat had the most delicate structure. Compared to wild boars, wild boar/domestic pig hybrids showed a decrease in the percentage of oxidative fibres and an increase in the percentage of glycolytic fibres. The diameters of all muscle fibre types in this group of animals were similar to those obtained in pigs. 


\section{References}

ASHTON, C.; BAYOL, S.; MCENTEE, G.; MALTBY, V.; STICKLAND, N.:

Prenatal influences on skeletal muscle development in mammals, birds and fish. Arch. Tierz. 48 (2005) Special Issue, $4-10$

BADER, R.:

Vergleichende histometrische und histologische Untersuchungen an der Skelettmuskulatur von Wildund Hausschweinen. Berl. Münch. Tierärztl. Wschr. 96 (1983), 89-97

BOGUCKA, J.; KAPELANSKI, W.:

Microstructure traits of longissimus lumborum muscle in Polish Landrace and crossbred Stamboek and Torhyb pigs. Anim. Sci. Pap. Rep. 22 (2004) 4, 419-427

BOGUCKA, J.; KAPELANSKI W.:

Microstructure of longissimus lumborum muscle in pigs of several breeds and its relation to meat quality traits. Folia Biol. 53 (Suppl.) (2005), 85-90

DUBOWITZ, W.; BROOKE, M.; NEVILLE, H.E.:

Muscle Biopsy: A Modern Approach. W.B. Saunders Company LTD London, Philadelphia, Toronto (1973)

ESSÉN-GUSTAVSSON, B.; LINDHOLM, A.:

Fiber types and metabolic characteristics in muscles of wild boars, normal and halothane sensitive Swedish landrace pigs. Comp. Biochem. Physiol. 78A 1 (1984), 67-71

POLISH ACADEMY OF SCIENCES. KIELANOWSKI INSTITUT OF ANIMAL PHYSIOLOGY AND

NUTRITION (ED.): Feeding standards for pigs. (1993) [in Polish]

FIEDLER, I.; REHFELDT, CH.; ALBERT, E.; HENNING, M.:

Histophysiological features of skeletal muscle and adrenal glands in wild-type and domestic pigs during growth (short communication). Arch. Tierz. 41 (1998) 5, 489-495

KLOSOWSKA, D.; GRZEŚKOWIAK, E.; ELMINOWSKA-WENDA, G.; WALASIK, K.; BOGUCKA, J.:

Microstructural characteristics of $M$. longissimus lumborum of the pigs synthetic line (Naïma x P-76) in relation with meatiness and some meat quality parameters. Ann. Anim. Sci. 2 (2002), 305-309

KLOSOWSKA, D.; GRZESKOWIAK, E.; LUTHER, R.; ELMINOWSKA-WENDA, G.:

Microstructural characteristics of longissimus muscle in synthetic hybrid line (PIC) pigs and meat quality. Pol. J. Food Nutr. Sci., Olsztyn 7/48, (1998)4, 167-172

KLOSOWSKA, D.; KURYL, J.; ELMINOWSKA-WENDA, G.; KAPELANSKI, W.; WALASIK, K.; PIERZCHALA, M.; CIESLAK, D.; BOGUCKA, J.:

An association between genotypes at the porcine loci MSTN (GDF8) and CAST and microstructural characteristics of $m$. longissimus lumborum: a preliminary study. Arch. Tierz. 48 (2005), 50-59

KLOSOWSKI, B.; KLOSOWSKA, D.; GOSZCZYNSKI, J.:

Muscle fiber types and their diameters in skeletal muscles of the European Bison, The hybrids of the European Bison x domestic cattle and lowland black-and-white cattle. Acta Acad. Agricult. Tech. Olst., Zoot., LIII Zjazd Nauk. PTZ, 14-16 September, Olsztyn (1988), 290-293 [in Polish]

KORZENIOWSKI, W.; BOJARSKA, U.; CIERACH, M.:

A slaughter value of wild boar. Med. Wet., Lublin 47 (1991) 4, 166-169 [in Polish]

LACHOWICZ, K.; ZOCHOWSKA, J.; SOBCZAK, M.:

Comparison of the texture and structure of selected muscles of piglets and wild boar juveniles. Pol. J.

Food Nutr. Sci., Olsztyn 13/54 (2004) 1, 75-79

LEFAUCHEUR, L.; ECOLAN, P.:

Pattern of muscle fiber formation in Large White and Meishan pigs. Arch. Tierz. 48 (2005) Special Issue, $117-122$

LEFAUCHEUR, L.; GERRARD, D.:

Muscle fiber plasticity in farm mammals. Proc. Am. Soc. Anim. Sci. (1998)

http://www.asas.org/jas/symposia/proceedings/0307.pdf

REHFELD, CH.:

Prenatal events that determine the number of muscle fibres are important for lean growth and meat quality in pigs. Arch. Tierz. 48 (2005) Special Issue, 11-22

REHFELDT, CH.; KUHN, G.:

Consequences of birth weight for postnatal growth performance and carcass quality in pigs as related to myogenesis. J. Anim. Sci. 84, Suppl. (2006), 113-123

RUUSUNEN, M.; PUOLANNE, E.:

Histochemical properties of fibre types in muscles of wild and domestic pigs and the effect of growth rate on muscle fibre properties. Meat Sci. 67 (2004) 3, 533-539 
SZENTKUTI, L.; SCHLEGEL, O.:

Genetische und funktionelle Einflüsse auf Fasertypenanteile und Faserdurchmesser im M. longissimus dorsi und M. semitendinosus von Schweinen. Untersuchungen an trainierten haus- und immobil gehalten Wildschweinen. Dtsch. Tierärtzl. Wschr. 92 (1985), 93

WALKIEWICZ, A.; WIELBO, E.; STASIAK, A.; MATYKA, S.; BABICZ, M.; KASPRZAK, A.; KAMYK, P.; LECHOWSKI, J.; LUBKOWSKA, D.:

Wild boar $\times$ domestic pig crosses - biological and practical aspects - a review. Pr. i Mat. Zoot., Zesz. Specj. 15 (2004), 65-75 [in Polish]

WATERS, R. E; ROTEVATN, S.; LI, P.; ANNEX, B. H.; YAN, Z.:

Voluntary runing induces fiber type-specific angiogenesis in mouse skeletal muscle. Am. J. Physiol. Cell Physiol. 287 (2004), C1342-C1348

WEILER, U.; APPELL, H.-J.; KREMSER, M.; HOFÄCKER, S.; CLAUS, R.:

Consequences of Selection on Muscle Composition. A Comparative Study on Gracilis Muscle in Wild and Domestic Pigs. Anat. Histol. Embryol. 24 (1995), 77-80

ZIEGAN, J.:

Kombinationen enzymhistochemischer Methoden zur Fasertypendifferenzierung und Beurteilung der Skeletmuskulatur. Acta Histochemica 65 (1979), 34-40

ZMIJEWSKI, T.; KORZENIOWSKI, W.:

Technological properties of wild boars meat. EJPAU, Food Sci. Technol. 4 (2001) 2

Received: 2007-07-07

Accepted: 2008-04-11

Authors:

Dr. JOANNA BOGUCKA

email: bogucka@utp.edu.pl

Dr. habil. GABRIELA ELMINOWSKA-WENDA

email: histol@utp.edu.pl

Dr. KONRAD WALASIK

email: walasik@utp.edu.pl

MSc Ing. KATARZYNA LIDIA LEWANDOWSKA

Devision of Animal Histology

Department of Animal Biotechnology

Prof. Dr. habil. WOJCIECH KAPELAŃSKI

email: kapelanski@utp.edu.pl

Department of Pig Breeding

Faculty of Animal Breeding and Biology

University of Technology and Life Sciences in Bydgoszcz

Mazowiecka 28

85-084 Bydgoszcz

Poland 